\title{
Relation between chronic periodontal disease and plasmatic levels of triglycerides, total cholesterol and fractions
}

\section{Relação entre doença periodontal crônica e os níveis plasmáticos de triglicérides, colesterol total e frações}

\author{
Ana Cristina Posch Machado* \\ Maria Rozeli de Souza Quirino** \\ Luiz Fernando Costa Nascimento***
}

\begin{abstract}
Many people in the world are affected by hyperlipidemia, which is a known risk factor for atherosclerotic disease. On the other hand, periodontitis, a prevalent oral disease, has been connected to several systemic health changes, including an altered lipid metabolism. Transient and recurrent bacteremias, which may be caused by periodontal infection, induce an intense local and systemic inflammatory response, leading to changes in the whole body. The aim of the present study was to verify the relationship between severe and moderate periodontal disease and blood lipid levels. Sixty individuals seen at the clinics of the University of Taubaté, São Paulo, over 20 years old, were divided into two groups, with and without periodontitis, and paired according to sex and age. Their levels of total cholesterol, tryglicerides and fractions were determined. Variables related to high cholesterol levels, including age, sex and body mass index, were evaluated. The values recommended by the Brazilian Society of Cardiology were considered to classify lipidemia. The results showed that mean levels of cholesterol (192.1 mg/ $\mathrm{dl} \pm 40.9)$ and triglycerides $(153.5 \mathrm{mg} / \mathrm{dl} \pm 105.6)$ in individuals with periodontitis were higher than, but not statistically different from, those of individuals without periodontitis $(186.1 \mathrm{mg} / \mathrm{dl} \pm 35.4$ and $117.5 \mathrm{mg} / \mathrm{dl} \pm 68$, respectively). Therefore, this study has demonstrated that there is no significant relationship between periodontal disease, regardless of its intensity, and blood lipid levels in the studied population.
\end{abstract}

DESCRIPTORS: Periodontal diseases; Hyperlipidemia; Cholesterol; Lipoproteins; Triglycerides.

\begin{abstract}
RESUMO: A doença periodontal crônica, bastante prevalente na população adulta, tem sido relacionada com diversas alterações sistêmicas, entre elas as dislipidemias, que são fatores de risco conhecidos para a aterosclerose. Bacteremias transitórias e recorrentes, que podem ser causadas pela infecção periodontal, levam a uma intensa resposta inflamatória local e sistêmica, promovendo modificações ao longo do corpo. A proposta do presente estudo foi verificar se a presença da doença periodontal, de moderada a severa, está relacionada com a elevação dos lipídios séricos. Participaram do estudo sessenta indivíduos, acima de vinte anos, divididos em grupo teste, com doença periodontal, e grupo controle, sem doença periodontal, pareados quanto ao gênero e à idade, provenientes da Clínica Odontológica da Universidade de Taubaté/SP, nos quais foram determinados os níveis de colesterol total, de frações e de triglicérides. Foram avaliadas também variáveis como idade, gênero e índice de massa corpórea. Para classificação da lipidemia, foram considerados os valores recomendados pela Sociedade Brasileira de Cardiologia. As médias dos valores do colesterol total $(192,1 \mathrm{mg} / \mathrm{dl} \pm 40,9)$ e dos triglicérides $(153,5 \mathrm{mg} / \mathrm{dl} \pm 105,6)$, no grupo teste, foram superiores às do grupo controle, $186,1 \mathrm{mg} / \mathrm{dl} \pm 35,4$ e $117,5 \mathrm{mg} / \mathrm{dl} \pm 68$, respectivamente, porém sem significância estatística. Concluiu-se, assim, que, na população estudada e com a metodologia empregada, a doença periodontal, independentemente da intensidade, não mostrou relação estatisticamente significante com a lipidemia.
\end{abstract}

DESCRITORES: Doenças periodontais; Hiperlipidemia; Colesterol; Lipoproteínas; Triglicerídeos.

\section{INTRODUCTION}

Chronic periodontitis is the most frequent form of the disease characterized by an inflammation of the tissues that support the teeth, which results in destruction of the periodontal ligament and loss of the adjacent bone that support the teeth $^{2}$. It affects a high number of individuals, specially adults, and promotes continuous exposure to bacteria, endotoxins (lipopolysaccharides) and

\footnotetext{
* MS in Periodontics, Professor, Discipline of Oral Pathology and Oral Diagnosis, Department of Dentistry; **PhD in Stomatology, Professor, Discipline of Oral Pathology and Oral Diagnosis, Department of Dentistry; ***PhD in Public Health, Professor, Department of Medicine - University of Taubaté.
} 
Machado ACP, Quirino MRS, Nascimento LFC. Relation between chronic periodontal disease and plasmatic levels of triglycerides, total cholesterol and fractions. Braz Oral Res 2005;19(4):284-9.

other bacterial products in both the periodontal tissue and the bloodstream, which can induce or maintain local and systemic inflammatory reactions in the host $\mathrm{t}^{5,20,22}$.

Recent studies have proven that periodontal disease can produce numerous changes in systemic health ${ }^{3,4,6}$, changing the blood chemistry with a rise in inflammatory mediators, proteins and lipids in the serum. These factors explain, at least in part, the probable association between periodontitis and the susceptibility for certain systemic diseases, such as the increased risk of cardiovascular disease, that presents high prevalence in the world.

Acute systemic or local chronic infections seem to induce changes in the plasmatic concentration of cytokines and hormones, which determine changes in the lipid metabolism ${ }^{1,9,19}$. The study of Feingold et al. ${ }^{7}$ (1992) showed that the administration of low doses of endotoxins in rats resulted in hypertriglyceridemia, suggesting the presence of a similar response in local infections such as periodontal disease, in which there is a chronic systemic exposure to microorganisms and lipopolysaccharides ${ }^{7,13}$.

The study of Memon et al. ${ }^{16}$ (1993) proved that the induction of periodontitis by Porphyromonas gingivalis in rats resulted in an increased level of triglycerides. And, more recently, using similar methodology, the same result was observed in the work of Doxey et al. ${ }^{6}$ (1998).

Through the analysis of the total cholesterol level, low density lipoproteins and triglycerides of individuals with periodontal disease, Cutler et al. ${ }^{3}$ (1999) and Lösche et al. ${ }^{14}$ (2000) showed that their plasmatic levels of these lipids were significantly higher than in healthy individuals. On the other hand, the study of Katz et al. ${ }^{11}$ (2002) evaluated the periodontal health of over ten thousand Israeli military service men and women and compared the results with their blood lipid levels and did not find a significant association between the presence of periodontal pockets and high levels of triglycerides.

Therefore, considering the diversity of the few developed studies, as well as the different eating habits and studied populations, new researches to establish the real systemic changes caused by periodontitis are appropriate in order to explain the metabolic and/or physiological changes responsible for changes in general health and in the increased susceptibility for certain systemic diseases.

Consequently, the purpose of the present study was to verify the relation between chronic periodontal disease, from moderate to severe, and the plasmatic levels of total cholesterol, low and high density lipoproteins and triglycerides.

\section{MATERIAL AND METHOD}

Individuals of both genders, over 20 years old, with no less than 10 teeth in the oral cavity, were used in this study. They were divided into two ageand sex-matched groups: a test group, composed of thirty individuals with chronic periodontal disease from moderate to severe ${ }^{2}$, with at least two periodontal pockets $\geq 5 \mathrm{~mm}$; and a control group, composed of 30 periodontally healthy individuals or with gingivitis.

The individuals were selected among those who seek treatment at the Dental Clinics of the University of Taubate, as well as among students, employees and professors of that institution. The individuals were informed of the nature of the study and signed an Informed Consent. This study was approved by the Research Ethics Committee, University of Taubate (UNITAU), under protocol number 036/02.

Individuals with diabetes, primary and secondary hyperlipidemia, with history of myocardial infarction or cancer, or that made use of diuretics, contraceptive agents, corticosteroids, anabolic steroids, and also those who had received periodontal treatment in the last six months and/or took cholesterol reduction medicine in the last two months before the beginning of this study were not included in the study.

The physical examination included measuring weight (in kilograms), using a portable Welmy scale (model R-100, Santa Bárbara do Oeste, Brazil), and height (in centimeters), using a tape measure. The obesity level was assessed through the Body Mass Index (BMI); individuals with $\mathrm{BMI} \geq 30$ were considered obese ${ }^{17}$. The clinical periodontal examination was performed with a surgical clamp, a plane mirror and a Willis periodontal millimeter probe. The clinical parameters evaluated were probing depth and clinical insertion loss, and also gingival ${ }^{12}$ and plaque ${ }^{23}$ indices.

The individuals had their blood sample collected at the Laboratorio de Análises Clínicas do Hospital Universitário da UNITAU (Clinical Analysis Laboratory, University Hospital, UNITAU), after a minimum twelve-hour fast, for the biochemistry analysis of the lipid and glycaemia levels. The enzymatic colorimetric method TG COLOR GPO/ PAP AA (WIENER LAB ${ }^{\circledR}$, Rosario, Argentina) was 
Machado ACP, Quirino MRS, Nascimento LFC. Relation between chronic periodontal disease and plasmatic levels of triglycerides, total cholesterol and fractions. Braz Oral Res 2005;19(4):284-9.

TABLE 1 - Mean Values, standard deviation (sd) and respective $p$ values of the variables according to the groups.

\begin{tabular}{l|r|r|r}
\hline \multirow{2}{*}{\multicolumn{1}{c|}{ Variable }} & Mean $\pm \mathrm{sd}$ & Mean $\pm \mathrm{sd}$ & $\begin{array}{c}\text { Student's } t \text { test } \\
(p \leq 0.05)\end{array}$ \\
\cline { 2 - 4 } & Test Group & Control Group & 0.66 \\
\hline Age (years) & $43.3 \pm 9.2$ & $44.3 \pm 9.7$ & 0.52 \\
\hline Body mass index $\left(\mathrm{kg} / \mathrm{m}^{2}\right)$ & $25.0 \pm 3.3$ & $24.4 \pm 2.6$ & 0.54 \\
\hline Total cholesterol $(\mathrm{mg} / \mathrm{dL})$ & $192.1 \pm 40.9$ & $186.1 \pm 35.4$ & 0.11 \\
\hline Triglycerides $(\mathrm{mg} / \mathrm{dL})$ & $153.5 \pm 105.6$ & $117.5 \pm 68.0$ & 0.95 \\
\hline LDL $(\mathrm{mg} / \mathrm{dL})$ & $115.9 \pm 39.6$ & $115.4 \pm 26.4$ & 0.88 \\
\hline HDL $(\mathrm{mg} / \mathrm{dL})$ & $46.1 \pm 14.0$ & $46.6 \pm 14.8$ & 0.93 \\
\hline Glucose $(\mathrm{mg} / \mathrm{dL})$ & $89.4 \pm 13.1$ & $89.1 \pm 16.6$ & 0.0002 \\
\hline Missing Teeth & $11.2 \pm 6.4$ & $5.5 \pm 3.4$ & \\
\hline \hline
\end{tabular}

LDL: low-density lipoproteins; HDL: high-density lipoproteins.

used to determine triglycerides (TG) in serum or plasma and the COLESTEROL liquiform System (LABTEST DIAGNÓSTICA S.A. ${ }^{\circledR}$, Lagoa Santa-MG, Brazil) was used to analyze total cholesterol (TC) and high-density lipoproteins (HDL). Low-density lipoproteins (LDL) was assessed according to the formula by Friedewald et al..$^{8}(1972)$, in which LDL = TC - (HDL + TG/5).

The lipid levels were classified according to the criteria of the Sociedade Brasileira de Cardiologia (Brazilian Society of Cardiology) $^{24}$.

Student's $t$ test was used to compare between the two means and chi-square test $\left(\mathrm{x}^{2}\right)$ was used to estimate the association between the category variables. The Kruskal-Wallis non-parametric test was used when the variances were not homogenous. The EPI INFO 6.04 program (Center for Disease Control and Prevention, Atlanta, USA) was used to analyze data, and the significance level was set at $5 \%$ ( $\mathrm{p} \leq 0.05)$. Pearson's Correlation Coefficient ( $\mathrm{r}$ ) was used to evaluate the correlation level between the blood lipid level and the number of lost teeth, at a $95 \%$ confidence level.

\section{RESULTS}

The sample of the study was composed of sixty individuals, 34 men (56.7\%) and 26 women (43.3\%) between 27 and 64 years old (mean \pm standard deviation: $43.8 \pm 9.4)$.

The global mean levels of total cholesterol, LDL, triglycerides and HDL were considered desirable according to their respective reference values ${ }^{24}$.

Sixty individuals were divided into two groups with thirteen women (43\%) and seventeen men $(57 \%)$. The age range for the control group
TABLE 2 - Correlation coefficient (r) and respective confidence interval of 95\% (CI 95\%) between the variables missing teeth and cholesterol, HDL, triglycerides and LDL.

\begin{tabular}{l|c|c}
\hline \hline \multicolumn{1}{c|}{ Variables } & $\mathrm{R}$ & $\mathrm{CI}(95 \%)$ \\
\hline $\begin{array}{l}\text { Missing teeth versus } \\
\text { cholesterol }\end{array}$ & 0.24 & $-0.02 ; 0.46$ \\
\hline Missing teeth versus HDL & -0.08 & $-0.33 ; 0.18$ \\
\hline $\begin{array}{l}\text { Missing teeth versus } \\
\text { triglycerides }\end{array}$ & 0.22 & $-0.04 ; 0.44$ \\
\hline Missing teeth versus LDL & 0.21 & $-0.05 ; 0.44$ \\
\hline \hline
\end{tabular}

was from 27 to 64 (mean \pm standard deviation: $44.3 \pm 9.7$ ) and only one individual was a smoker. The age range for the test group was from 28 to 61 (mean \pm standard deviation: $43.3 \pm 9.2$ ), with two smokers.

The summary of the statistical analysis of the clinical parameters and lipid and glucose levels for test and control groups are shown in Table 1.

Among the individuals of the test group, 83.3\% presented severe periodontitis and $16.7 \%$, moderate periodontitis.

Graphs 1 to 3 represent the total cholesterol, triglycerides and LDL levels (desirable, borderline and high) observed in the sample studied. Graph 4 shows the prevalence of HDL, desirable or not.

Positive correlations were observed for the absence of teeth with total cholesterol, triglycerides, LDL and negative correlation was observed with HDL. However, no statistical significance was observed between all of them (Table 2). On the other hand, there was a positive correlation between tooth loss and age $(\mathrm{R}=0.47 ; \mathrm{P}<0.001)$. 
Machado ACP, Quirino MRS, Nascimento LFC. Relation between chronic periodontal disease and plasmatic levels of triglycerides, total cholesterol and fractions. Braz Oral Res 2005;19(4):284-9.

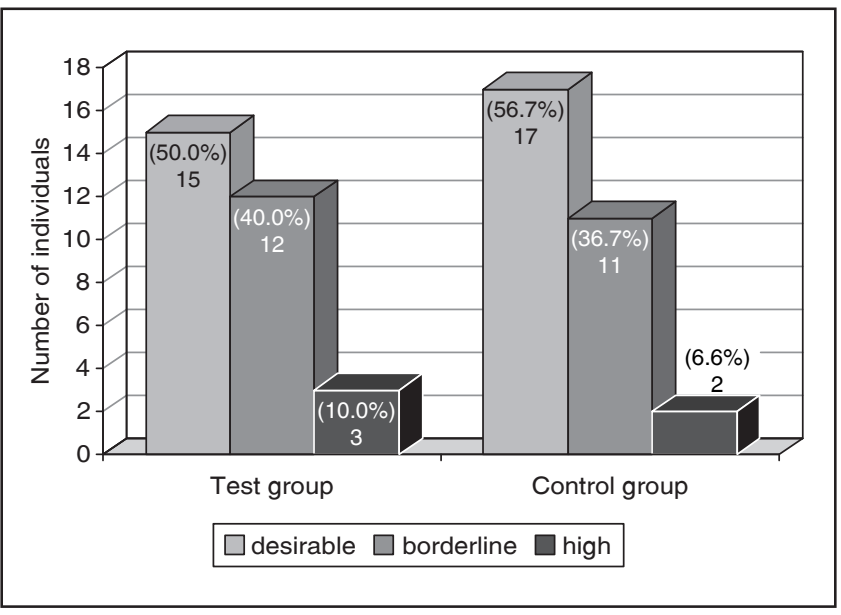

GRAPH 1 - Distribution of individuals and respective percentages according to the total cholesterol levels of the different groups studied.

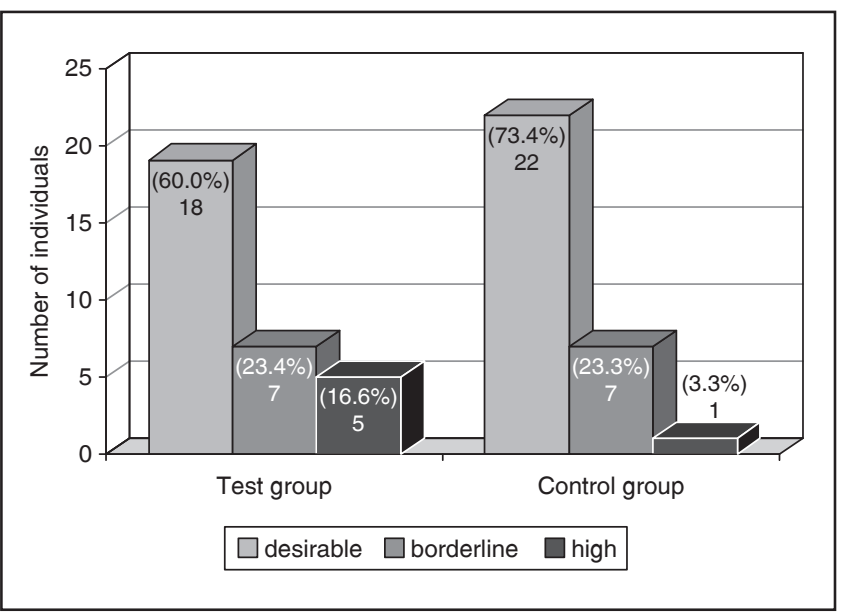

GRAPH 3 - Distribution of individuals and respective percentages according to the low-density lipoprotein levels of the different groups studied.

\section{DISCUSSION}

Periodontitis is an inflammatory, chronic, destructive disease that affects the tissues that support the teeth. The complex correlation between microorganisms, its products and the host's defense mechanisms, innate and acquired, determine the result of the periodontal disease, whose progression is not linear but sporadic ${ }^{25}$. Although few studies have been performed on the issue, it is known that the prevalence of the periodontal disease in the Brazilian population is high.

On the other hand, presently, there is a great concern with the blood lipid level, since the rise

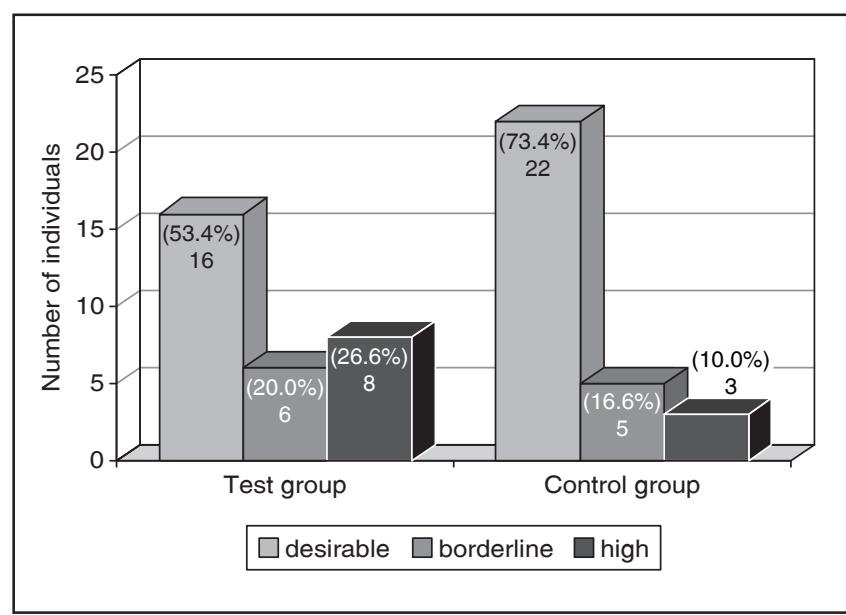

GRAPH 2 - Distribution of individuals and respective percentages according to the triglycerides levels of the different groups studied.

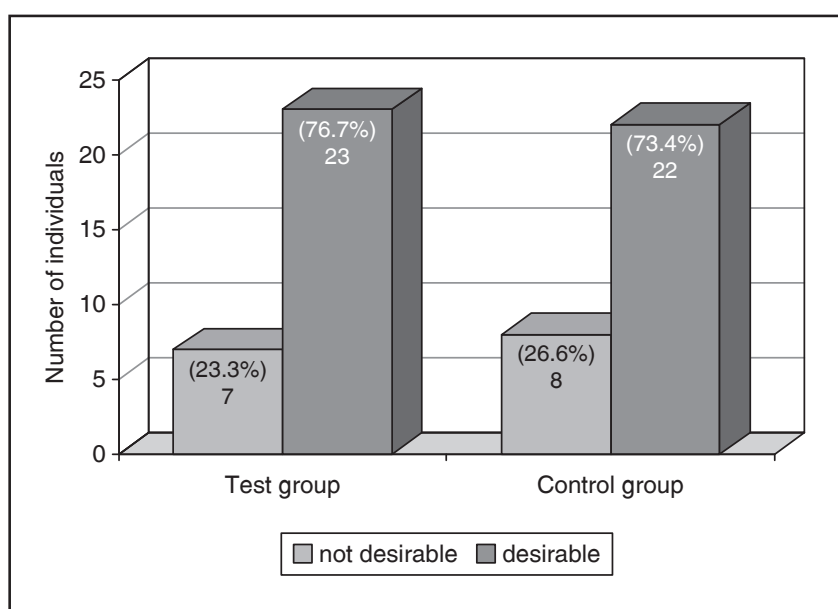

GRAPH 4 - Distribution of individuals and respective percentages according to the high-density lipoprotein levels of the different groups studied.

of these rates represent and important risk factor for cardiovascular diseases ${ }^{21}$. The prevalence of hyperlipidemia is still scarcely established, and the results of the studies are controversial. Moreover, such prevalence is geographically variable, depending on the cultural or acquired eating habits, as well as on the life style of the different populations.

The present study was based on the results of some researches with animal and human models $^{3,7,14}$ that suggest that the periodontal disease can raise blood lipid levels. Although we found higher total cholesterol and triglycerides levels in the test group, and also more frequent pathological values of serum lipids, the results were not statisti- 
Machado ACP, Quirino MRS, Nascimento LFC. Relation between chronic periodontal disease and plasmatic levels of triglycerides, total cholesterol and fractions. Braz Oral Res 2005;19(4):284-9.

cally significant as those of the works of Cutler et al. ${ }^{3}$ (1999) and Lösche et al. ${ }^{14}$ (2000).

Cutler et al. ${ }^{3}$ (1999) showed a significant association between periodontitis and hyperlipidemia, in relation to the triglycerides and total cholesterol levels. However, the groups were not age-matched, and the mean age of the group with disease was 50.5 years, statistically higher than that of the control group, 41.6 years.

Similar methodology was used in the study of Lösche et al. ${ }^{14}$ (2000) in which the authors observed significantly higher total cholesterol levels, LDL and triglycerides in the group with periodontal disease in comparison to the group without the disease. In this study, the groups were not sexmatched, but only age-matched. The mean of the group with the disease was 54.8 years old, different from that observed in our study, 44.3 years old. Considering that the cholesterol levels increase with age ${ }^{10,18}$, even though the groups were agematched, a difference is expected since the mean age of our study was lower.

Only one study, performed by Katz et al. ${ }^{11}$ (2002), found in the literature verified the degree of obesity, another important factor since it leads to disturbances in general health conditions, such as psychological changes, hypertension, cardiovascular diseases, hyperlipidemia, among others. Overweight affects about $1 / 3$ of the adult popula-

\section{REFERENCES}

1. Alvarez C, Ramos A. Lipids, lipoproteins, and apoproteins in serum during infection. Clin Chem 1986;32:142-5.

2. American Academy of Periodontology. International Workshop for a classification of periodontal diseases and conditions. Ann Periodontol 1999;4:1-112.

3. Cutler CW, Shinedling EA, Nunn M, Jotwani R, Kim BO, Nares S, et al. Association between periodontitis and hiperlipidemia: cause or effect? J Periodontol 1999;70:142934.

4. Danesh J, Collins R, Appleby P, Peto R. Association of fibrinogen, C-reactive protein, albumin, or leukocyte count with coronary heart disease: meta-analyses of prospective studies. JAMA 1998;279:1477-82.

5. Dinarello C. Interleukin-1, interleukin-1 receptors and interleukin-1 receptor antagonist. Int Rev Immunol 1998;16:457-99.

6. Doxey DL, Cutler CW, Iacopino AM. Diabetes prevents periodontitis-induced increases in gengival PDGF-B and IL-1 $\beta$ in a rat model. J Periodontol 1998;69:113-9.

7. Feingold KR, Staprans I, Memon RA, Moser AH, Shigenaga JK, Doerrler W, et al. Endotoxin rapidly induces changes in lipid metabolism that produce hypertriglyceridemia: low doses stimulate hepatic triglyceride production while high doses inhibit clearance. J Lipid Res 1992;33:1765-76. tion and presents a growing tendency in the last decades $^{26}$. In the present study there was no statistically significant difference between the BMI of the test and control groups.

Tooth loss has been described as a risk factor for cardiovascular disease ${ }^{15}$. In our study we verified a positive correlation between tooth loss and the levels of TC, LDL and triglycerides and a negative correlation between tooth loss and the levels of HDL; there was a statistically significant correlation between tooth loss and age.

Finally, the disagreements observed in the studies that relate periodontal disease with hyperlipidemia may be in part due to the great number of variables involved such as eating and physical activity habits, socio-economical conditions, obesity, age and stress, which are factors subjected to the environment in which the individual lives, interfering with the study results since they are situations that are difficult to control.

\section{CONCLUSION}

Based on the results of the present study, it can be concluded that there was no significant statistical relationship between chronic periodontal disease and the plasmatic levels of total cholesterol, low- and high-density lipoproteins and triglycerides in the studied population.

8. Friedewald WT, Levy RI, Fredrickson DS. Estimation of the concentration of low-density lipoprotein in plasma without use of the preparative ultracentrifuge. Clin Chem 1972;18:499-502.

9. Gallin JI, Kaye D, O'Leary WM. Serum lipids in infection. N Engl J Med 1969;281:1081-6.

10. Guimarães AC, Lima A, Mota E, Lima JC, Martinez T, Conti AF, et al. The cholesterol level of a selected Brazilian salaried population. CVD Prevention 1998;1:306-17.

11. Katz J, Flugelman MY, Goldberg A, Heft M. Association between periodontal pockets and elevated cholesterol and low density lipoprotein cholesterol levels. J Periodontol 2002;73:494-500.

12. Loe H, Silness J. Periodontal disease in pregnancy. I. Prevalence and severity. Acta Odontol Scand 1963;21:533-51.

13. Loesche WJ. Periodontal disease: link to cardiovascular disease. Compend Contin Educ Dent 2000;21:463-82.

14. Losche W, Karapetow F, Pohl A, Pohl C, Kocher T. Plasma lipid and blood glucose levels in patients with destrutive periodontal disease. J Clin Periodontol 2000;27:537-41.

15. Mattila KJ, Valtonen VV, Nieminen M, Huttunen JK. Dental infection and the risk of new coronary events: prospective study of patients with documented coronary artery disease. Clin Infect Dis 1995;20:588-92. 
Machado ACP, Quirino MRS, Nascimento LFC. Relation between chronic periodontal disease and plasmatic levels of triglycerides, total cholesterol and fractions. Braz Oral Res 2005;19(4):284-9.

16. Memon RA, Grunfeld C, Moser AH, Feingold KR. Tumor necrosis factor mediates the effects of endotoxin on cholesterol and triglyceride metabolism in mice. Endocrinology 1993;132(5):2246-53.

17. National Heart, Lung, and Blood Institute. Clinical guidelines on the identification, evaluation, and treatment of overweight and obesity in adults. The evidence report (September 1998). Available from: URL: http://www.nhlbi. nih.gov/guidelines/obesity/ob_gdlns.htm.

18. Nicolau JC, Nogueira C, Maia LN, Ramires JAF. Trends in cholesterol levels in the adult population of São José do Rio Preto (1991-1997). Arq Bras Cardiol 1998;71:699704.

19. Prabu A, Michalowicz BS, Mathur A. Detection of local and systemic cytocines in adult periodontitis. J Periodontol 1996;67:515-22.

20. Salvi GE, Yalda B, Collins JG, Jones BH, Smith FW, Arnold RR, et al. Inflammatory mediator response as a potential risk marker for periodontal diseases in Insulin-dependent diabetes mellitus patients. J Periodontol 1997;68:127-35.

21. Santos RD, Sociedade Brasileira de Cardiologia. III Brazilian Guidelines on Dyslipidemias and Guideline of Ath- erosclerosis Prevention from Atherosclerosis Department of Sociedade Brasileira de Cardiologia. Arq Bras Cardiol 2001;77 Suppl 3:1-48

22. Scannapieco FA. Position paper of the American Academy of Periodontology: Periodontal disease as a potential risk factor for systemic diseases. J Periodontol 1998;69:841-50.

23. Silness J, Loe H. Periodontal disease in pregnancy II. Correlation between oral hygiene and periodontal condition. Acta Odontol Scand 1964;22:121-35.

24. Sociedade Brasileira de Cardiologia. II Consenso Brasileiro sobre Dislipidemias. Detecção, Avaliação e Tratamento. Arq Bras Cardiol 1996;67:113-8. Disponivel em: URL: http://www.cardiol.br/sbc-funcor/projetos/prodatha/exerc.asp.

25. Socransky SS, Haffajee AD, Cugini MA, Smith C, Kent RL Jr. Microbial complexes in subgingival plaque. J Clin Periodontol 1998;25:134-44.

26. World Health Organization. Obesity: preventing and managing the global epidemic. Report of a WHO Consultation. Geneva; 2000. (WHO - Technical Report Series, 894).

Received for publication on Oct 06, 2004

Sent for alterations on Jun 29, 2005 Accepted for publication on Oct 05, 2005 